Kong Mun Lo, See Mun Lee and Edward R.T. Tiekink*

\title{
Crystal structure of catena-\{[tri-aqua-di-sodium bis(2-\{[n-butyl(methyl)carbamothioyl]sulfanyl\} acetate) $\}_{n},\left[\mathrm{C}_{16} \mathrm{H}_{34} \mathrm{~N}_{2} \mathrm{Na}_{2} \mathrm{O}_{7} \mathrm{~S}_{4}\right]_{\mathrm{n}}$
}
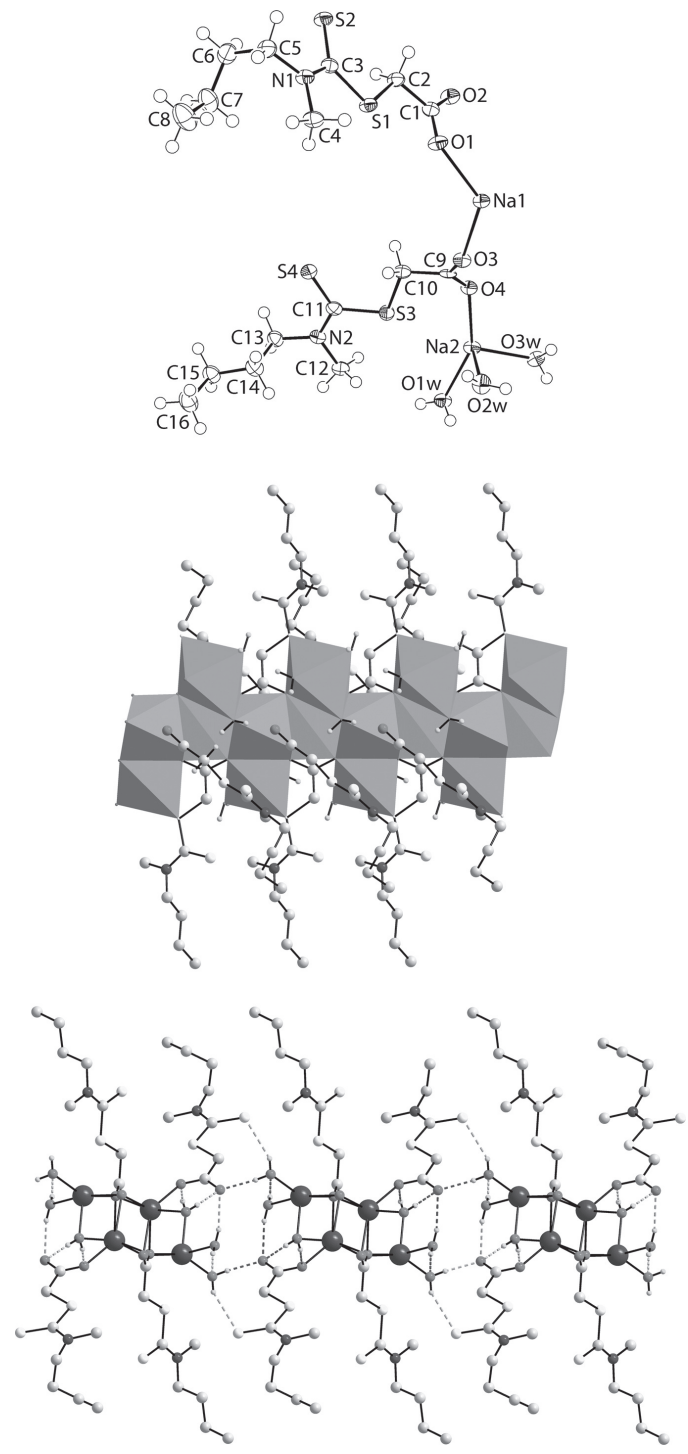

*Corresponding author: Edward R.T. Tiekink, Research Centre for Crystalline Materials, School of Science and Technology, Sunway University, 47500 Bandar Sunway, Selangor Darul Ehsan, Malaysia, e-mail:edwardt@sunway.edu.my,Edward.Tiekink@gmail.com. https://orcid.org/0000-0003-1401-1520

Kong Mun Lo and See Mun Lee: Research Centre for Crystalline Materials, School of Science and Technology, Sunway University, 47500 Bandar Sunway, Selangor Darul Ehsan, Malaysia https://doi.org/10.1515/ncrs-2019-0513

Received July 19, 2019; accepted August 21, 2019; available online October 4, 2019

\begin{abstract}
$\left[\mathrm{C}_{16} \mathrm{H}_{34} \mathrm{~N}_{2} \mathrm{Na}_{2} \mathrm{O}_{7} \mathrm{~S}_{4}\right]_{\mathrm{n}}$, triclinic, $P \overline{1}$ (no. 2), $a=5.3734(1) \AA$, $b=11.0473(2) \AA, \quad c=22.2264(5) \AA, \quad \alpha=102.075(2)^{\circ}$, $\beta=96.202(2)^{\circ}, \quad \gamma=97.383(2)^{\circ}, \quad V=1267.06(5) \AA^{3}, \quad Z=2$, $R_{\mathrm{gt}}(F)=0.0335, w R_{\text {ref }}\left(F^{2}\right)=0.0941, T=100(2) \mathrm{K}$.
\end{abstract}

CCDC no.: 1948407

The constituents of the asymmetric unit are shown in the figure. Table 1 contains crystallographic data and Table 2 contains the list of the atoms including atomic coordinates and displacement parameters.

Table 1: Data collection and handling.

\begin{tabular}{ll}
\hline Crystal: & Colourless plate \\
Size: & $0.17 \times 0.04 \times 0.02 \mathrm{~mm}$ \\
Wavelength: & Cu $K \alpha$ radiation $(1.54178 \AA$ A $)$ \\
$\mu:$ & $4.12 \mathrm{~mm}^{-1}$ \\
Diffractometer, scan mode: & XtaLAB Synergy, $\omega$ \\
$\theta_{\text {max }}$, completeness: & $67.1^{\circ},>99 \%$ \\
$N(h k l)_{\text {measured }}, N(h k l)_{\text {unique }}, R_{\text {int }}:$ & $30669,4523,0.040$ \\
Criterion for $I_{\text {obs }}, N(h k l)$ gt: & $I_{\text {obs }}>2 \sigma\left(I_{\text {obs }}\right), 4210$ \\
$N(\text { param })_{\text {refined }}:$ & 302 \\
Programs: & CrysAlis \\
& WinG $[1]$, SHELX [2, 3], ORTEP [4]
\end{tabular}

\section{Source of material}

All chemicals and solvents were used as purchased without purification. The melting point was determined using a Meltemp II digital melting point apparatus and was uncorrected. The solid-state IR spectrum was obtained on a Bruker Vertex $70 v$ FTIR Spectrometer from 4000 to $400 \mathrm{~cm}^{-1}$. The ${ }^{1} \mathrm{H}$ and ${ }^{13} \mathrm{C}\left\{{ }^{1} \mathrm{H}\right\}$ NMR spectra were recorded at room temperature in $\mathrm{CDCl}_{3}$ solution on a Bruker Ascend $400 \mathrm{MHz}$ NMR spectrometer with chemical shifts relative to tetramethylsilane.

The dithiocarbamate ligand was prepared in situ (acetone) from the reaction of $\mathrm{CS}_{2}$ (Merck, $0.25 \mathrm{mmol}$ ) with n-butylmethylamine (Merck, $0.25 \mathrm{mmol}$ ) and $\mathrm{NaOH}$ (0.02 mL; $50 \% \mathrm{w} / \mathrm{v}) ; \mathrm{CS}_{2}$ was added dropwise into the methanol solution 
Table 2: Fractional atomic coordinates and isotropic or equivalent isotropic displacement parameters $\left(\AA^{2}\right)$.

\begin{tabular}{|c|c|c|c|c|}
\hline Atom & $x$ & $y$ & $z$ & $U_{\text {iso }} * / U_{\text {eq }}$ \\
\hline $\mathrm{S} 1$ & $1.14745(10)$ & $0.13521(5)$ & $0.31092(3)$ & $0.01677(13)$ \\
\hline $\mathrm{S} 2$ & $1.20238(10)$ & $-0.12848(5)$ & $0.24774(3)$ & $0.01810(14)$ \\
\hline S3 & $-0.09303(11)$ & $0.55782(5)$ & $0.30283(3)$ & $0.01951(14)$ \\
\hline $\mathrm{S} 4$ & $0.07497(11)$ & $0.40808(5)$ & $0.18787(3)$ & $0.01860(14)$ \\
\hline 01 & $0.8756(3)$ & $0.23449(14)$ & $0.40388(8)$ & $0.0185(3)$ \\
\hline 02 & $0.6459(3)$ & $0.06077(15)$ & $0.41707(8)$ & $0.0195(3)$ \\
\hline 03 & $0.4094(3)$ & $0.51778(14)$ & $0.42949(7)$ & $0.0163(3)$ \\
\hline 04 & $0.0078(3)$ & $0.54681(14)$ & $0.43245(7)$ & $0.0158(3)$ \\
\hline N1 & $1.4657(4)$ & $0.08311(18)$ & $0.23274(9)$ & $0.0171(4)$ \\
\hline N2 & $-0.2638(4)$ & $0.56527(18)$ & $0.19006(9)$ & $0.0175(4)$ \\
\hline $\mathrm{C} 1$ & $0.8092(4)$ & $0.1187(2)$ & $0.39188(11)$ & $0.0158(4)$ \\
\hline $\mathrm{C} 2$ & $0.9367(4)$ & $0.0355(2)$ & $0.34436(11)$ & $0.0173(5)$ \\
\hline $\mathrm{H} 2 \mathrm{~A}$ & 0.8070 & -0.0189 & 0.3114 & $0.021^{*}$ \\
\hline $\mathrm{H} 2 \mathrm{~B}$ & 1.0333 & -0.0188 & 0.3649 & $0.021 *$ \\
\hline $\mathrm{C} 3$ & $1.2883(4)$ & $0.0276(2)$ & $0.26040(10)$ & $0.0156(4)$ \\
\hline $\mathrm{C} 4$ & $1.5381(4)$ & $0.2203(2)$ & $0.24791(12)$ & $0.0197(5)$ \\
\hline $\mathrm{H} 4 \mathrm{~A}$ & 1.3916 & 0.2592 & 0.2363 & $0.030^{*}$ \\
\hline $\mathrm{H} 4 \mathrm{~B}$ & 1.6758 & 0.2432 & 0.2249 & 0.030 * \\
\hline $\mathrm{H} 4 \mathrm{C}$ & 1.5950 & 0.2497 & 0.2926 & 0.030 * \\
\hline $\mathrm{C} 5$ & $1.5901(4)$ & $0.0086(2)$ & $0.18504(11)$ & $0.0204(5)$ \\
\hline $\mathrm{H} 5 \mathrm{~A}$ & 1.6369 & -0.0653 & 0.1995 & $0.024^{\star}$ \\
\hline $\mathrm{H} 5 \mathrm{~B}$ & 1.7481 & 0.0599 & 0.1799 & $0.024^{*}$ \\
\hline $\mathrm{C} 6$ & $1.4227(5)$ & $-0.0357(2)$ & $0.12220(12)$ & $0.0250(5)$ \\
\hline $\mathrm{H} 6 \mathrm{~A}$ & 1.2690 & -0.0904 & 0.1273 & 0.030 * \\
\hline H6B & 1.5155 & -0.0871 & 0.0930 & $0.030^{*}$ \\
\hline $\mathrm{C} 7$ & $1.3407(5)$ & $0.0692(3)$ & $0.09316(12)$ & $0.0287(6)$ \\
\hline $\mathrm{H} 7 \mathrm{~A}$ & 1.2108 & 0.0320 & 0.0566 & $0.034^{\star}$ \\
\hline H7B & 1.2616 & 0.1255 & 0.1237 & $0.034^{\star}$ \\
\hline $\mathrm{C} 8$ & $1.5590(6)$ & $0.1466(3)$ & $0.07287(14)$ & $0.0369(7)$ \\
\hline $\mathrm{H} 8 \mathrm{~A}$ & 1.6828 & 0.1887 & 0.1093 & $0.055^{*}$ \\
\hline $\mathrm{H} 8 \mathrm{~B}$ & 1.4935 & 0.2095 & 0.0530 & $0.055^{*}$ \\
\hline $\mathrm{H} 8 \mathrm{C}$ & 1.6409 & 0.0914 & 0.0433 & $0.055^{*}$ \\
\hline $\mathrm{C} 9$ & $0.1897(4)$ & $0.51760(19)$ & $0.40392(10)$ & $0.0131(4)$ \\
\hline $\mathrm{C} 10$ & $0.1442(4)$ & $0.4765(2)$ & $0.33315(11)$ & $0.0163(4)$ \\
\hline $\mathrm{H} 10 \mathrm{~A}$ & 0.0865 & 0.3849 & 0.3204 & $0.020^{*}$ \\
\hline $\mathrm{H} 10 \mathrm{~B}$ & 0.3040 & 0.4956 & 0.3162 & 0.020 * \\
\hline $\mathrm{C} 11$ & $-0.1018(4)$ & $0.5105(2)$ & $0.22109(11)$ & $0.0166(5)$ \\
\hline $\mathrm{C} 12$ & $-0.4020(4)$ & $0.6599(2)$ & $0.22157(11)$ & $0.0194(5)$ \\
\hline $\mathrm{H} 12 \mathrm{~A}$ & -0.5205 & 0.6213 & 0.2452 & 0.029 * \\
\hline $\mathrm{H} 12 \mathrm{~B}$ & -0.4964 & 0.6946 & 0.1907 & 0.029 * \\
\hline $\mathrm{H} 12 \mathrm{C}$ & -0.2818 & 0.7273 & 0.2499 & 0.029 * \\
\hline C13 & $-0.3042(4)$ & $0.5392(2)$ & $0.12204(11)$ & $0.0197(5)$ \\
\hline $\mathrm{H} 13 \mathrm{~A}$ & -0.4853 & 0.5384 & 0.1075 & $0.024^{\star}$ \\
\hline $\mathrm{H} 13 \mathrm{~B}$ & -0.2621 & 0.4552 & 0.1052 & $0.024^{*}$ \\
\hline C14 & $-0.1418(5)$ & $0.6370(2)$ & $0.09735(11)$ & $0.0223(5)$ \\
\hline $\mathrm{H} 14 \mathrm{~A}$ & -0.1658 & 0.7218 & 0.1189 & $0.027^{*}$ \\
\hline H14B & 0.0391 & 0.6295 & 0.1070 & $0.027^{\star}$ \\
\hline C15 & $-0.2070(5)$ & $0.6224(2)$ & $0.02784(11)$ & $0.0229(5)$ \\
\hline $\mathrm{H} 15 \mathrm{~A}$ & -0.3840 & 0.6364 & 0.0186 & $0.028^{*}$ \\
\hline H15B & -0.1959 & 0.5355 & 0.0065 & $0.028^{*}$ \\
\hline $\mathrm{C} 16$ & $-0.0323(5)$ & $0.7133(3)$ & $0.00220(13)$ & $0.0309(6)$ \\
\hline $\mathrm{H} 16 \mathrm{~A}$ & -0.0551 & 0.7994 & 0.0200 & $0.046^{*}$ \\
\hline $\mathrm{H} 16 \mathrm{~B}$ & -0.0737 & 0.6956 & -0.0431 & $0.046^{*}$ \\
\hline $\mathrm{H} 16 \mathrm{C}$ & 0.1442 & 0.7032 & 0.0132 & $0.046^{*}$ \\
\hline $\mathrm{Na} 1$ & $0.70753(15)$ & $0.40096(8)$ & $0.46389(4)$ & $0.01489(19)$ \\
\hline
\end{tabular}

Table 2 (continued)

\begin{tabular}{lrrrr}
\hline Atom & $\boldsymbol{x}$ & $\boldsymbol{y}$ & $\boldsymbol{z}$ & $\boldsymbol{U}_{\text {iso }}{ }^{*} \boldsymbol{U}_{\text {eq }}$ \\
\hline Na2 & $-0.26699(16)$ & $0.69607(8)$ & $0.43202(4)$ & $0.0169(2)$ \\
O1W & $-0.5177(3)$ & $0.81183(15)$ & $0.38060(8)$ & $0.0201(3)$ \\
H1W & $-0.587(5)$ & $0.800(3)$ & $0.3438(6)$ & $0.030^{*}$ \\
H2W & $-0.450(5)$ & $0.8867(13)$ & $0.3939(12)$ & $0.030^{*}$ \\
O2W & $0.0821(3)$ & $0.85602(17)$ & $0.45241(8)$ & $0.0247(4)$ \\
H3W & $0.135(5)$ & $0.891(3)$ & $0.4898(6)$ & $0.037^{*}$ \\
H4W & $0.206(4)$ & $0.839(3)$ & $0.4337(12)$ & $0.037^{*}$ \\
O3W & $-0.3720(3)$ & $0.75892(15)$ & $0.53094(8)$ & $0.0184(3)$ \\
H5W & $-0.247(4)$ & $0.755(3)$ & $0.5561(10)$ & $0.028^{*}$ \\
H6W & $-0.447(5)$ & $0.817(2)$ & $0.5469(12)$ & $0.028^{\star}$ \\
\hline
\end{tabular}

(10 mL). The resulting mixture solution was kept at $273 \mathrm{~K}$ for $1 \mathrm{~h}$. Sodium chloroacetate (Merck, $0.03 \mathrm{~g}, 0.25 \mathrm{mmol}$ ) was added into the solution. The filtrate was evaporated slowly until a white precipitate was formed. The precipitate was washed with $n$-hexane and recrystallized from a methanolacetone solution. Colourless crystals of the title salt were obtained from the slow evaporation of the solvent. Yield: 0.027 g (20.0\%). M.pt: >623 K. IR $\left(\mathrm{cm}^{-1}\right) 1570(\mathrm{~s})$ v(C-0), $1486(\mathrm{~s}) v(\mathrm{C}-\mathrm{N}), 1382(\mathrm{~s}) v(\mathrm{C}-\mathrm{N}), 1117(\mathrm{~m}) v(\mathrm{C}-\mathrm{O}), 1012(\mathrm{~m})$ $v(\mathrm{C}-\mathrm{S}), 980(\mathrm{~m}) v(\mathrm{C}-\mathrm{S}) .{ }^{1} \mathbf{H}$ NMR $\left(\mathrm{CDCl}_{3}\right.$, p.p.m.): $\delta 0.93$ (s, $\left.3 \mathrm{H}, \mathrm{CH}_{3}\right), 1.20-1.44$ (m, 4H, $\left.\mathrm{CH}_{2} \mathrm{CH}_{2}\right), 2.80-2.82\left(\mathrm{~m}, 2 \mathrm{H}, \mathrm{CH}_{2}\right)$, 2.87-2.90 (m, 6H, water- $\mathrm{OH}), 3.44\left(\mathrm{~s}, 3 \mathrm{H}, \mathrm{NCH}_{3}\right), 4.00-4.04$ (m, 4H, $\left.\mathrm{NCH}_{2}\right) .{ }^{13} \mathbf{C}\left\{{ }^{1} \mathbf{H}\right\}$ NMR $\left(\mathrm{CDCl}_{3}\right.$, p.p.m.): $13.9\left(\mathrm{CH}_{3}\right), 20.0$, $28.5\left(\mathrm{CH}_{2} \mathrm{CH}_{2}\right), 40.0\left(\mathrm{SCH}_{2}\right), 43.6\left(\mathrm{NCH}_{3}\right), 57.0\left(\mathrm{NCH}_{2}\right), 175.2$ (CO), $197.2\left(\mathrm{CS}_{2}\right)$.

\section{Experimental details}

The C-bound $\mathrm{H}$ atoms were geometrically placed $(\mathrm{C}-\mathrm{H}=0.98-0.99 \AA)$ and refined as riding with $U_{\text {iso }}(\mathrm{H})=1.2-$ $1.5 U_{\text {eq }}(\mathrm{C})$. The $\mathrm{O}$-bound $\mathrm{H}$-atoms were located in a difference Fourier map but were refined with a distance restraint $\mathrm{O}-\mathrm{H}=0.84 \pm 0.01 \AA$, and with $U_{\text {iso }}(\mathrm{H})$ set to $1.5 U_{\text {eq }}(\mathrm{O})$. A number of reflections were omitted from the final cycles of refinement owing to poor agreement; details are given in the CIF.

\section{Comment}

The title sodium salt of a hybrid dithiocarbamate ester of a carboxylic acid, isolated as a trihydrate, was investigated as a part of on-going studies of the structural chemistry of these molecules [5] and their organotin derivatives [6]. The motivation for these studies is to ultimately investigate the biological potential of the organotin derivatives, as both organotin carboxylates [7] and organotin dithiocarbamates [8] are known to exhibit a range of pharmaceutical potential. Indeed, a very recent publication highlighted the potential anti-tumour activity of several organotin species containing 
these molecules [9]. The structure of the substituted tribenzyl tin complex comprising the same dithiocarbamate anion reported in this publication has also been reported in the literature [10].

The constituents comprising the asymmetric unit of the title salt hydrate are shown in the upper view of the figure (70\% displacement ellipsoids) and comprise two independent sodium cations, two $n-\mathrm{Bu}(\mathrm{Me}) \mathrm{NC}(=\mathrm{S}) \mathrm{SCH}_{2} \mathrm{CO}_{2}$ anions and three water molecules of crystallization. The pattern in $\mathrm{C}-\mathrm{S}$ bond lengths, with $\mathrm{C} 3-\mathrm{S} 3$ [1.682(2) $\AA$ ] being significantly shorter than C3-S1 [1.762(2) Å] and C2-S1 [1.804(2) Å] match those involving the S3 and S4 atoms [1.675(2), 1.776(2) and 1.802(2) A, respectively. Further, they follow the pattern established in another dithiocarbamate ester, i.e. recently determined $\operatorname{MeSC}(=\mathrm{S}) \mathrm{N}(\mathrm{Me}) \mathrm{Ph}$ [11], with equivalent values being 1.6590(18), 1.7662(17) and 1.789(2) Å. Further, the pattern in the angles about the $\mathrm{C} 3$ atom, with the wider angles subtended by the S2 atom $[\mathrm{S} 1-\mathrm{C} 3-\mathrm{S} 2=122.81(13) \AA$ and $\mathrm{S} 2-$ $\mathrm{C} 3-\mathrm{N} 1=124.12(17) \AA$. $c f . \mathrm{S} 1-\mathrm{C} 3-\mathrm{N} 1=113.06(16) \AA]$ is consistent with the presence of a $\mathrm{C} 3=\mathrm{S} 2$ and $\mathrm{C} 11=\mathrm{S} 4$ thione bonds, as the equivalent angles about the $\mathrm{C} 11$ atom follow the same trends $\left[\mathrm{S} 3-\mathrm{C} 11-\mathrm{S} 4=122.93(14)^{\circ}, \mathrm{S} 4-\mathrm{C} 11-\mathrm{N} 2=124.66(18)^{\circ}\right.$ and $\left.\mathrm{S} 3-\mathrm{C} 11-\mathrm{N} 2=112.41(17)^{\circ}\right]$. Further, in a recently authenticated dithiocarbamate anion, ${ }^{-} \mathrm{S}_{2} \mathrm{CN}\left(\mathrm{CH}_{2} \mathrm{CH}_{2}\right)_{2} \mathrm{NPh}$ [12], the angles about the quaternary-carbon atom spanned a very narrow range $119.45(8)$ to $120.57(10)^{\circ}$, consistent with significant delocalization of $\pi$-electron density over the $\mathrm{CS}_{2}$ chromophore, clearly absent in the anions of the title compound. The above descriptors are consistent with the presence of carboxylate groups in the anions. However, the $\mathrm{C}-\mathrm{O}$ bond lengths are not equivalent $[\mathrm{C} 1-01, \mathrm{O} 2=1.247(3)$

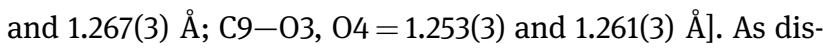
cussed below, these variations are related to the different interactions the carboxylate- $\mathrm{O}$ atoms have with the sodium cations and in the supramolecular assembly. There is a significant difference in the conformations of the carboxylate ligands. While the $\mathrm{CO}_{2}$ and $\mathrm{CS}_{2}$ residues are close to co-planar in the O1-carboxylate anion, with the $\mathrm{CO}_{2} / \mathrm{CS}_{2}$ dihedral angle being $4.5(5)^{\circ}$, these are inclined in the 03 carboxylate anion with the $\mathrm{CO}_{2} / \mathrm{CS}_{2}$ dihedral angle being $32.55(16)^{\circ}$. This conformational difference arises from variable twists about the $\mathrm{O} 1-\mathrm{C} 1-\mathrm{C} 2-\mathrm{S} 1\left[-5.0(3)^{\circ}\right]$ and $\mathrm{O} 3-\mathrm{C} 9-$ C10-S3 torsion angles $\left[-148.67(16)^{\circ}\right]$. The other conformational difference in the carboxylate anions relates to the $n$ butyl groups. Thus, in the 01-carboxylate anion, the $\mathrm{N} 1-\mathrm{C} 5-$ $\mathrm{C} 6-\mathrm{C} 7\left[60.2(3)^{\circ}\right]$ and $\mathrm{C} 5-\mathrm{C} 6-\mathrm{C} 7-\mathrm{C} 8\left[68.2(3)^{\circ}\right]$ torsion angles are indicative of + syn-clinal conformation whereas the equivalent $\mathrm{N} 2-\mathrm{C} 13-\mathrm{C} 14-\mathrm{C} 15\left[-172.0(2)^{\circ}\right]$ and $\mathrm{C} 13-\mathrm{C} 14-\mathrm{C} 15-\mathrm{C} 16$ $\left[-175.6(2)^{\circ}\right]$ torsion angles indicate an - anti-periplanar conformation.
The sodium cations have quite distinct donor sets and coordination geometries. The Na1 cation is coordinated by six oxygen atoms, five of which are carboxylate- $O$ and the sixth being a water-O atom. The Na1-O bond lengths range from 2.3443(18) $\AA$, for Na1-03, to 2.5370(18) $\AA$ for Na1- $4^{\mathrm{i}}$ [symmetry operation (i) $1-x, 1-y, 1-z$ ]. The $\mathrm{O}_{6}$ donor set defines a distorted trigonal prismatic geometry. By contrast, the $\mathrm{Na} 2$ cation is coordinated within a $\mathrm{O}_{5} \mathrm{~S}$ donor set defined by two carboxylate- $\mathrm{O}$, three water$\mathrm{O}$ and thioester-S atoms. The Na2-O bonds range from 2.3161(19) $\AA$, for $\mathrm{Na} 2-\mathrm{O} 3 \mathrm{w}$, to 2.4410 (18) $\AA$, for $\mathrm{Na} 2-\mathrm{O}^{\mathrm{ii}}$ [(ii) $-1+x, y, z]$ and define a square-pyramidal geometry. The S3 atom occupies the sixth site [Na2-S3=3.2502(11) $\AA$ ] leading to a distorted octahedral geometry. As seen in the middle view of the figure, the aforementioned connections give rise to a one-dimensional chain along the $a$ axis with edge-shared coordination polyhedra. The inner polyhedra encompass the Na1-cations and the outer polyhedra contain the Na2-cations. Additional stability to the one-dimensional coordination polymer arises from hydrogen bonding interactions of the type water- $\mathrm{O}-\mathrm{H} \cdots \mathrm{O}$ (carboxylate, water) $\quad\left[\mathrm{O} 2 \mathrm{w}-\mathrm{H} 3 \mathrm{w} \cdots \mathrm{O} 2^{\mathrm{i}}: \quad \mathrm{H} 3 \mathrm{w} \cdots \mathrm{O} 2^{\mathrm{i}}=2.192(16) \AA\right.$, $\mathrm{O} 2 \mathrm{w} \cdot \cdots \mathrm{O} 2^{\mathrm{i}}=3.003(2) \AA$ with angle at $\mathrm{H} 3 \mathrm{w}=162(3)^{\circ} ; \mathrm{O} 2 \mathrm{w}-$ H4w $\cdots$ O $1 \mathrm{w}^{\mathrm{iii}}: \quad \mathrm{H} 4 \mathrm{w} \cdots \mathrm{O} 1 \mathrm{w}^{\mathrm{iii}}=2.01(2) \AA, \quad 02 \mathrm{w} \cdots \mathrm{O} 1 \mathrm{w}^{\mathrm{iii}}=$ 2.845(2) $\AA$, with angle at $\mathrm{H} 4 \mathrm{~W}=172(3)^{\circ}$; $\quad 03 \mathrm{w}-$ $\mathrm{H} 5 \mathrm{w} \cdot \cdots \mathrm{O} 1^{\mathrm{i}}: \mathrm{H} 5 \mathrm{w} \cdots \mathrm{O} 1^{\mathrm{i}}=2.07(2) \AA, 03 \mathrm{w} \cdot \cdots \mathrm{O} 1^{\mathrm{i}}=2.879(2) \AA$ with angle at $\mathrm{H} 5 \mathrm{w}=161(2)^{\circ}$ and $03 \mathrm{w}-\mathrm{H} 6 \mathrm{w} \cdots \mathrm{O} 2^{\mathrm{iv}}$ : $\mathrm{H} 6 \mathrm{w} \cdot \mathrm{OO} 2^{\mathrm{iv}}=1.93(3) \AA, \mathrm{O} 3 \mathrm{w} \cdot \mathrm{O} 2^{\mathrm{iv}}=2.762(2) \AA$ with angle at $\mathrm{H} 6 \mathrm{w}=175(3)^{\circ}$ for (iii) $1+x, y, z$ and (iv) $-x, 1-y$, $1-z]$. The connections between the chains along the $b$ axis to form a supramolecular layer are of the type water-

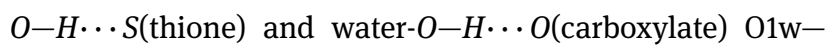

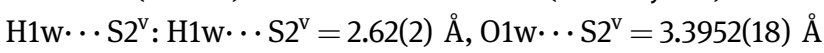
with angle at $\mathrm{H} 1 \mathrm{w}=154(3)^{\circ}$ and $\mathrm{O} 1 \mathrm{w}-\mathrm{H} 2 \mathrm{w} \cdots \mathrm{O} 2^{\mathrm{vi}}$ : $\mathrm{H} 2 \mathrm{w} \cdots \mathrm{O} 2^{\mathrm{vi}}=1.872(17) \AA, \quad \mathrm{O} 1 \mathrm{w} \cdots \mathrm{O} 2^{\mathrm{vi}}=2.699(2) \AA \quad$ with angle at $\mathrm{H} 2 \mathrm{w}=170(3)^{\circ}$ for $(\mathrm{v})-2+x, 1+y, z$ and $(\mathrm{vi})-1+x$, $1+y, z]$. The layers stack along the $c$ axis direction without directional interactions between them.

Further analysis of the molecular packing was performed using Crystal Explorer 17 [13] to calculate the Hirshfeld surfaces (including the full and delineated twodimensional fingerprint plots) for the specified asymmetric unit (see figure), following standard procedures [14]. Reflecting, to a large extent, the hydrophobic contacts along the $c$ axis, $\mathrm{H} \cdots \mathrm{H}$ contacts make the greatest contribution to the overall Hirshfeld surface, at 52.5\%. The next most significant contribution to the surface contacts are $\mathrm{S} \cdots \mathrm{H} / \mathrm{H} \cdots \mathrm{S}$ at $17.1 \%$ followed closely by $\mathrm{O} \cdots \mathrm{H} / \mathrm{H} \cdots \mathrm{H}$ [14.6\%], then $\mathrm{Na} \cdots \mathrm{O} / \mathrm{O} \cdots \mathrm{Na}[7.7 \%]$ and $\mathrm{C} \cdots \mathrm{H} / \mathrm{H} \cdots \mathrm{C}[3.9 \%]$ contacts. An accompanying structural report of a closely related sodium 
salt, $\mathrm{Na}\left[\mathrm{S}_{2} \mathrm{CN}(\mathrm{Me}) \mathrm{n}-\mathrm{Bu}\right] \cdot \mathrm{H}_{2} \mathrm{O}$ [15], also adopts a layer structure with the layers separated by hydrophobic interactions. The percentage contribution by $\mathrm{H} \cdot \cdot \mathrm{H}$ contacts to the Hirshfeld surface also computes to $52.5 \%$ in this crystal [15].

Acknowledgements: Sunway University Sdn Bhd is thanked for financial support of this work through Grant No. STRRCTR-RCCM-001-2019.

\section{References}

1. Rigaku Oxford Diffraction. CrysAlis ${ }^{\text {PRO }}$. Rigaku Corporation, Oxford, UK (2018).

2. Sheldrick, G. M.: A short history of SHELX. Acta Crystallogr. A64 (2008) 112-122.

3. Sheldrick, G. M.: Crystal structure refinement with SHELXL. Acta Crystallogr. C71 (2015) 3-8.

4. Farrugia, L. J.: WinGX and ORTEP for Windows: an update. J. Appl. Crystallogr. 45 (2012) 849-854.

5. Lee, S. M.; Azizan, A. H. S.; Lo, K. M.; Tan, S. L.; Tiekink, E. R. T.: 2-\{[bis(propan-2-yl)carbamothioyl]sulfanyl\}acetic acid. Molbank 2019 (2019) M1082 (seven pages).

6. Lee, S. M.; Lo, K. M.; Tiekink, E. R. T.: Crystal structure of bis $\left[\left(\mu_{3}\right.\right.$-oxido)-( $\mu_{2}$-( $N, N$-diisopropylthiocarbamoylthio) acetato- $\left.\mathrm{K}^{2} \mathrm{O}, \mathrm{O}^{\prime}\right)-((\mathrm{N}, \mathrm{N}$-diisopropylthiocarbamoylthio)acetato$\mathrm{KO}$ )-bis(di-4-methylbenzyl-tin(IV))], $\mathrm{C}_{100} \mathrm{H}_{136} \mathrm{~N}_{4} \mathrm{O}_{10} \mathrm{~S}_{8} \mathrm{Sn}_{4}$. Z. Kristallogr. NCS 234 (2019) 943-946.

7. Gielen, M.; Tiekink, E. R. T.: Metallotherapeutic drugs and metal-based diagnostic agents: the use of metals in medicine.
(Eds. Gielen, M. and Tiekink, E. R. T.), p. 421-439. John Wiley \& Sons Ltd., Chichester, England (2005).

8. Tiekink, E. R. T.: Tin dithiocarbamates: applications and structures. Appl. Organomet. Chem. 22 (2008) 533-550.

9. Anasamy, T.; Thy, C. K.; Lo, K. M.; Chee, C. F.; Yeap, S. K.; Kamalidehghan, B.; Chung, L. Y.: Tribenzyltin carboxylates as anticancer drug candidates: effect on the cytotoxicity, motility and invasiveness of breast cancer cell lines. Eur. J. Med. Chem. 125 (2017) 770-783.

10. Keng, T. C.; Lo, K. M.; Ng, S. W.: $\{[(N-B u t y l-N$ methylcarbamothioyl)sulfanyl]acetato-kO\}tris(2-chlorobenzyl) tin(IV). Acta Crystallogr. E66 (2010) m307.

11. Lo, K. M.; Lee, S. M.; Tiekink, E. R. T.: Crystal structure of $N$ methyl- $\mathrm{N}$-phenyl(methylsulfanyl)carbothioamide, $\mathrm{C}_{9} \mathrm{H}_{11} \mathrm{NS}_{2}$. Z. Kristallogr. NCS 234 (2019) 1325-1327.

12. Lo, K. M.; Lee, S. M.; Tiekink, E. R. T.: Crystal structure of 4-phenylpiperazin-1-ium (4-phenylpiperazin-1-yl) carbothioylsulfanide, $\left[\mathrm{C}_{10} \mathrm{H}_{15} \mathrm{~N}_{2}\right]\left[\mathrm{C}_{11} \mathrm{H}_{13} \mathrm{~N}_{2} \mathrm{~S}_{2}\right]$. Z. Kristallogr. NCS 234 (2019) 1329-1331.

13. Turner, M. J.; McKinnon, J. J.; Wolff, S. K.; Grimwood, D. J.; Spackman, P. R.; Jayatilaka, D.; Spackman, M. A.: Crystal Explorer v17. The University of Western Australia, Australia (2017).

14. Tan, S. L.; Jotani, M. M.; Tiekink, E. R. T.: Utilizing Hirshfeld surface calculations, non-covalent interaction $(\mathrm{NCl})$ plots and the calculation of interaction energies in the analysis of molecular packing. Acta Crystallogr. E75 (2019) 308-318.

15. Lo, K. M.; Lee, S. M.; Zaldi, N. B.; Hussen, R. S. D.; Tiekink, E. R. T.: Crystal structure of catena-\{di-aqua-sodium [ $n$-butyl(methyl)carbamothioyl]sulfanide $\}_{n},\left[\mathrm{C}_{6} \mathrm{H}_{16} \mathrm{NNaO}_{2} \mathrm{~S}_{2}\right]_{n}$. Z. Kristallogr. NCS 234 (2019) 1333-1335. 